PROFESI (Profesional Islam)

Media Publikasi Penelitian; 2018; Volume 15; No 2.

Website: ejournal.stikespku.ac.id

\title{
Pengaruh Pemberian Terapi Murottal terhadap Penurunan Kecemasan Post Operasi
}

\author{
Firman Faradisi $^{1^{*}}$, Nurul Aktifah ${ }^{2}$ \\ 1,Prodi D III Keperawatan, STIKES Muhammadiyah Pekajangan Pekalongan \\ ${ }^{2}$ Prodi S1 Fisioterapi, STIKES Muhammadiyah Pekajangan Pekalongan \\ *Email: firman87pkj@gmail.com
}

\section{Kata Kunci}

Terapi Murottal, kecemasan setelah operasi

\begin{abstract}
Abstrak
Pasien yang mengalami nyeri akut, pengobatan untuk kecemasan sangat dibutuhkan, karena kecemasan sering meningkatkan persepsi rasa sakit, namun rasa sakit juga bisa menimbulkan rasa cemas. Kecemasan bisa menekan sistem kekebalan tubuh dan menyebabkan gangguan penyembuhan luka. Tujuan penelitian ini adalah untuk mengetahui efektifitas terapi murottal terhadap penurunan kecemasan post operasi open reduction and internal fixation (ORIF) pada pasien fraktur. Terapi yang digunakan untuk menurunkan kecemasan adalah memperdengarkan terapi murottal menggunakan Mp3 selama 15 menit tiap sesi, dan diberikan sebanyak 2 sesi dalam 2 hari. Penelitian ini menggunakan rancangan eksperimental pre-post test. Pasien fraktur ekstremitas yang dijadwalkan dilakukan operasi ORIF, secara acak dialokasikan ke dalam dua kelompok dengan menggunakan bilangan acak yang dihasilkan komputer. Pengumpulan data menggunakan VASA (skala analog visual untuk kecemasan). Analisis data menggunakan uji mixed repeated ANOVA. Dari tabel uji multivariat didapatkan p-value $=<0,001$ ( $p$ $<0,05)$, artinya ada perbedaan skor kecemasan antara kelompok murrotal dan kelompok kontrol. Berdasarkan uji dependent T- test, diketahui bahwa skor kecemasan pada pre-test dan post-test $<0,001(p<0,05)$, artinya setelah terapi murottal pada hari pertama dan kedua penelitian, skor kecemasan posttest menurun secara signifikan.
\end{abstract}

\section{The Effect of Murottal Therapy on Anxiety Decrease of Post Surgery Patients}

\section{Keywords}

Murottal Therapy, Anxiety post surgery

\section{Abstract}

Patient who have acute pain, the treatment for anxiety is needed, because anxiety often increase the perception of pain, but pain can also raise feeling of anxiety. Anxiety can suppress the immune system and lead to impaired wound healing. The purpose of this study is to investigate the effectiveness of murottal therapy to decrease anxiety, post operation of open reduction and internal fixation (ORIF) in fracture patients. The therapy used to reduce anxiety was by playing murottal therapy using Mp3 for 15 minutes each session, and given 2 sessions in 2 days. This study used an experimental pre-post test design. The patients which are scheduled for ORIF surgery, were randomly allocated into two groups using random numbers generated by the computer. Data collection using VASA (Visual analog scale for anxiety). Data analysis using mixed repeated ANOVA test. From themultivariate test table $p$-value $=<0.001(p$ $<0.05)$. It mean thatthere were differences inanxiety scores between murrotalgroupandcontrol group. Based on thetabledependent t-test, it was known thatanxiety scoresatpre-testto post-test $<0.001(p<0.05)$, it was mean thataf termurottal therapyonthe first and second day ofthe study, anxiety posttestscoresdecreased significantly 


\section{PENDAHULUAN}

Berdasarkan sistematik review oleh Capeda et al (2006); Alerd et al (2010), mencatat bahwa penggunaan terapi musik dapat menurunkan rasa sakit, namun penurunan hanya sedikit dan signifikasi klinisnya tidak pasti. Penelitian terdahulu menyarankan agar tidak hanya memeriksa nyeri tetapi juga mencakup kecemasan. Untuk pasien yang alami nyeri akut, pengobatan untuk kecemasan sangat dibutuhkan, karena kecemasan sering meningkatkan persepsi rasa sakit, namun rasa sakit juga bisa menimbulkan rasa cemas. Stimulus yang menyakitkan mengaktifkan bagian sistem limbik yang diyakini mengendalikan emosi seseorang, terutama kecemasan (potter dan Perry, 2006). Berdasarkan Chapman \& Gavrin (1999), rasa sakit yang terus berlanjut dapat menyebabkan gangguanfisik maupun mental. Stres psikologis sebagai kecemasan bisa menekan sistem kekebalan tubuh dan menyebabkan gangguan penyembuhan luka (Cave \& DiPietro, 2010). Kecemasan adalah sinyal yang memperingatkan adanya bahaya dan memungkinkan seseorang untuk mengambil tindakan untuk mengatasi ancaman tersebut (Kaplan, Sadock, \& Grebb, 2010). Dari sintesis kajian literatur menghasilkan teori psiko-fisiologis, yang mengurangi denyut jantung, tingkat pernafasan dan kecemasan (Lai, 2004).

Beberapa penelitian telah dilakukan dengan menggunakan musik untuk kecemasan pasca operasi, namun penelitian ini memiliki hasil yang beragam (Allerd, et al., 2010). Beberapa penelitian menunjukkan adanya penurunan kecemasan pasca operasi namun penelitian lain tidak. Penelitian tentang musik untuk pengelolaan kecemasan dan nyeri pasca operasi juga telah diteliti oleh Comeaux dan Moses, (2013) hasil penelitian ini tidak berpengaruh pada kecemasan, namun, menunjukkan bahwa terapi musik mengurangi rasa sakit.

Dari penelitian sebelumnya, ada beberapa prosedur yang dapat mempengaruhi hasil penelitian, seperti tidak menggunakan random untuk membagi pasien menjadi kelompok intervensi dan kontrol. Kurangnya ukuran sampel dan penggunaan musik yang kurang sesuai untuk pasien. Studi sebelumnya menjelaskan bahwa efek unsur musik, seperti nada dan tempo dapat mempengaruhi respons fisiologis. Berdasarkan temuan ini, beberapa peneliti hanya menggunakan satu jenis musik yang mungkin tidak sesuai dengan kriteria populasi dan budaya. Penting untuk dicatat bahwa budaya dan agama mempengaruhi cara orang menanggapi rasa sakit dan musik. Perbedaan berbasis budaya dalam musik terbukti dalam berbagai kombinasi nada, rhtym, tempo, melodi, harmoni dan makna yang dibawa musik kepada orang-orang. Berdasarkan penelitian Faradisi (2010) mengenai perbandingan terapi musik klasik dengan terapi murotal terhadap kecemasan pra operasi pada pasien dewasa di Indonesia, menunjukkan bahwa terapi murottal secara statistik memperoleh $\mathrm{p}<0,05$ dalam mengurangi kecemasan. Hal ini dikarenakan masyarakat Indonesia tidak mengenal musik klasik. Sementara murottal adalah dimensi seni yang ada dalam Islam dan ini sangat dikenal masyarakat Islam khususnya di Indonesia'. Selain itu, musik religius dan folk (musik rakyat yang penuh kesederhanaan dan keseharian dalam lagunya) di negara lain memiliki arti khusus bagi orang-orang yang telah dewasa mendengarkan lirik dan suaranya (Krumhansl., 2000; Good and Ahn, 2008).

Terapi musik telah banyak diterapkan sebagai alternatif untuk mempercepat penyembuhan, namun tidak banyak yang mengetahui bahwa terapi pembacaan Al-Quran (murottal) juga bisa membantu proses penyembuhan (Faradisi, 2010). Penelitian lain yang dilakukan oleh Ahmad al Khadi, managing director Islamic Medicine Institute for Education and Research di Florida, Amerika Serikat. Pada konferensi tahunan American Medical Association yang ketujuh belas, wilayah Missuori A.S., Ahmad Al-Qadi membuat presentasi tentang hasil penelitiannya dengan tema pengaruh murottal terhadap perspektif fisiologi manusia dan psikologi. Hasil penelitian ini menunjukkan hasil positif bahwa mendengarkan ayat-ayat Al-Quran memiliki efek signifikan dalam mengurangi ketegangan fibril yang reflektif dan hasil ini dicatat dan diukur secara kuantitatif dan kualitatif oleh alat berbasis komputer (Islamic Organization for Medical Sciences, 2001). Meski membaca Al-Quran (murottal) bukanlah musik atau puisi, namun fakta yang menarik adalah jika Al-Quran dibaca dengan menggunakan peraturan yang benar maka akan menghadirkan ritme musik yang indah, karena unsur dasar musik seperti ritme, nada dan tempo juga ada di Al-Quran (Shihab, 1998; Akbar, 2009). 
PROFESI (Profesional Islam)

Media Publikasi Penelitian; 2018; Volume 15; No 2.

Website: ejournal.stikespku.ac.id

\section{METODE PENELITIAN}

Penelitian ini menggunakan rancangan quasi eksperimental pre-post test. Peneliti menguji efek murottal pada kecemasan pasca operasi. Pasien yang memenuhi syarat diambil dari daftar bedah yang diberikan oleh rumah sakit, sesuai dengan kriteria inklusi dan kemudian dibagi secara acak ke kelompok intervensi dan kontrol. Pasien secara acak dialokasikan ke dalam dua kelompok dengan menggunakan bilangan acak yang dihasilkan komputer. Peserta dalam kelompok intervensi menerima analgesik (prosedur standar dari rumah sakit) kemudian diberikan 15 menit terapi murottal. Peserta dalam kelompok kontrol menerima analgesik dan beristirahat dengan tenang selama 15 menit. Kecemasan diukur sebelum dan segera setelah pemberian terapi murottal. Hasil penelitian lebih lanjut dibandingkan melalui uji statistik. Penelitian dilakukan pada pasien pasca operasi ORIF, di Rumah Sakit Karima Utama, Surakarta. Analisis data menggunakan uji mixed repeated ANOVA.

Instrumen untuk intervensi adalah file murottal dan Mp3 / headhpone. Untuk mengukur tingkat kecemasan subjektif responden dalam penelitian ini menggunakan VASA / visual analog sclae untuk kecemasan. Validitas VASA telah diteliti oleh Hornblow, \& Kidson, (1976) diuji terhadap dua kelompok, yaitu pasien rawat inap dan mahasiswa kedokteran jiwa. Instrumen ini, terbukti bermanfaat untuk mengukur kecemasan. Keandalan VASA telah diteliti oleh Lim Hook dkk (2008), pada pasien bedah wanita, diberi terapi musik dan dinilai tingkat kecemasannya. Hasil test retest reliability penelitian Lim Hook adalah 0,96 ( $<$.001) (Lim Hook et al., 2008).

Rumus yang digunakan dalam penelitian ini menurut Bhandari \& Joenisson (2010), adalah rumus untuk menghitung data continues dengan mengacu perbedaan nilai mean, yaitu;

$$
\begin{aligned}
n 1=n 2= & \frac{2 \sigma^{2}\left[Z_{1-\alpha}+Z_{1-\beta}\right]^{2}}{\Delta^{2}} \\
n 1=n 2= & \frac{2(20)^{2}(1,96+0,84)^{2}}{15^{2}} \\
& \frac{800 \times 7.84}{225} \\
= & 27.87 \\
= & 28
\end{aligned}
$$

Total $\mathrm{n} 1=\mathrm{n} 2=56$ tambah $10 \%$ untuk mencegah drop out $=62$ (tiap kelompok 31$)$.

Dari hasil penghitungan sampel ditemukan jumlah total $\mathrm{n} 1=\mathrm{n} 2=56$ ditambah $10 \% .31$ untuk intervensi dan 31 untuk kontrol grup.

\section{HASIL DAN PEMBAHASAN}

Data karakteristik responden berupaumur, jenis kelamin dan pengalaman pembedahan.

Table 1. Distribusi Responden

\begin{tabular}{lcccc}
\hline \multicolumn{1}{c}{ Variable } & $\begin{array}{c}\text { Murottal } \\
\text { Group } \\
\mathrm{N} \%\end{array}$ & $\begin{array}{c}\text { Control } \\
\text { group } \\
\mathrm{N} \%\end{array}$ & Total & $\%$ \\
\hline $\begin{array}{l}\text { Umur } \\
\begin{array}{l}\text { Dewasa muda } \\
\text { (18-30 tahun) }\end{array}\end{array}$ & 929.0 & 1032.3 & 19 & 30.6 \\
$\begin{array}{l}\text { Dewasa tengah } \\
\text { (31-60 years) }\end{array}$ & 2271.0 & 2167.7 & 43 & 69.4 \\
$\begin{array}{l}\text { Total } \\
\text { Gender }\end{array}$ & 31100.0 & 31100.0 & 62 & 100 \\
$\begin{array}{l}\text { Laki-laki } \\
\text { Perempuan }\end{array}$ & 2167.7 & 2167.7 & 42 & 67.7 \\
$\begin{array}{l}\text { Total } \\
\text { Riwayat }\end{array}$ & 31100.3 & 1032.3 & 20 & 32.3 \\
pembedahan & & & 62 & 100 \\
$\begin{array}{l}\text { Tidak pernah } \\
\text { Pernah }\end{array}$ & 2374.2 & 2477.4 & 47 & 75.8 \\
Total & 825.8 & 722.6 & 15 & 24.2 \\
\hline
\end{tabular}

Tabel 2. Tingkat kecemasan rata-rata distribusi frekuensi responden pada kelompok kontrol dan intervensi sebelum dan sesudah intervensi pada hari pertama sampai hari kedua di Rumah Sakit Karima Surakarta(N=62; $1=31, \mathrm{n} 2=31)$

\begin{tabular}{lcc}
\hline \multicolumn{1}{c}{ Variable } & $\begin{array}{c}\text { Intervensi } \\
\text { murottal } \\
\text { M SD }\end{array}$ & $\begin{array}{c}\text { kontrol } \\
\text { M SD }\end{array}$ \\
\hline $\begin{array}{l}\text { Hari 1 } \\
\text { Kecemasan } \\
\text { pretest }\end{array}$ & $\mathrm{n}=31$ & $\mathrm{n}=31$ \\
$\begin{array}{l}\text { Kecemasan } \\
\text { posttest }\end{array}$ & 38.032 .51 & 47.643 .01 \\
$\begin{array}{l}\text { Hari 2 } \\
\text { Kecemasan } \\
\text { pretest }\end{array}$ & 47.254 .54 & 46.294 .21 \\
$\begin{array}{l}\text { Kecemasan } \\
\text { posttest }\end{array}$ & 37.194 .40 & 46.544 .31 \\
\hline
\end{tabular}

Note; $\mathrm{M}=$ mean, $\mathrm{SD}=$ Standard deviation .

Kecemasan di ukur dengan 100-mm VASA. 
PROFESI (Profesional Islam)

Media Publikasi Penelitian; 2018; Volume 15; No 2.

Website: ejournal.stikespku.ac.id

\subsection{Tes Multivariatdalam mixed repeated ANOVA}

Tes multivariat terdiri dari 4 jenis tes, tes Pillai's Trace, Wilks 'Lamda, Hotel's Trace dan Roy's Root Terbesar. Ketentuan dari tes ini adalah jika sig $(\mathrm{p}<0,05)$, maka ada perbedaan antar perlakuan. Hasil uji multivariat terhadap kecemasan adalah sebagai berikut:

Tabel 3. tes multivariat dalam mixed ANOVA

\begin{tabular}{|c|c|c|c|}
\hline & & & nxiety \\
\hline & Effect & Sig. & $\begin{array}{l}\text { Partial Eta } \\
\text { Squared }\end{array}$ \\
\hline Test & Pillai's Trace & .000 & .723 \\
\hline & Wilks' Lambda & .000 & .723 \\
\hline & Hotelling's Trace & .000 & .723 \\
\hline & $\begin{array}{l}\text { Roy's Largest } \\
\text { Root }\end{array}$ & .000 & .723 \\
\hline test $*$ & Pillai's Trace & .000 & .614 \\
\hline group & Wilks' Lambda & .000 & .614 \\
\hline & Hotelling's Trace & .000 & .614 \\
\hline & $\begin{array}{l}\text { Roy's Largest } \\
\text { Root }\end{array}$ & .000 & .614 \\
\hline
\end{tabular}

Dari tabel uji multivariat $\mathrm{p}$-value $=<0,001$ $(\mathrm{p}<0,05)$. Artinya ada perbedaan skor kecemasan antara kelompok murrotal dan kelompok kontrol

\subsection{Analysis pairwase comparisons (Tes Perbedaan)}

Table 4. pairwase comparisons untuk kecemasan

\begin{tabular}{|c|c|c|c|}
\hline \multirow{2}{*}{\multicolumn{2}{|c|}{ (I) test $(\mathrm{J})$ test }} & \multicolumn{2}{|c|}{ anxiety } \\
\hline & & Std. Error & Sig. ${ }^{a}$ \\
\hline \multirow[t]{3}{*}{1} & 2 & .483 & .000 \\
\hline & 3 & .571 & 1.000 \\
\hline & 4 & .624 & .000 \\
\hline \multirow[t]{3}{*}{2} & 1 & .483 & .000 \\
\hline & 3 & .753 & .000 \\
\hline & 4 & .668 & 1.000 \\
\hline \multirow[t]{3}{*}{3} & 1 & .571 & 1.000 \\
\hline & 2 & .753 & .000 \\
\hline & 4 & .694 & .000 \\
\hline \multirow[t]{3}{*}{4} & 1 & .624 & .000 \\
\hline & & .668 & 1.000 \\
\hline & & .694 & .000 \\
\hline
\end{tabular}

Note: Test $1=$ pretes day 1 , Test $2=$ postest day 1 , Test $3=$ pretest day 2 , Test $4=$ postest day 2 .

\subsection{Tes Hypothesis}

Hipotesis I: Ada perbedaan tingkat kecemasan pasca operasi pasien yang telah menjalani operasi ORIF di antara kelompok intervensi yang mendapat terapi murottal dan kelompok kontrol.

Jika dilihat dari analisis hasil penelitian, terapi murottal terbukti valid dapat mengurangi kecemasan dibandingkan dengan kelompok kontrol terdapat perbedaan yang signifikan, uji variabel dan uji interaksi * kelompok baik pada kecemasan menghasilkan hasil yang signifikan untuk semua tes multivariat $\mathrm{p}$-Value $=<0,001(\mathrm{p}$ $<0,05$ ). Artinya ada perbedaan skor kecemasan antara kelompok murrotal dan kelompok kontrol. Dari tabel perkiraan dapat dilihat bahwa rata-rata skor anxiety group murrotal lebih rendah dari rata-rata kelompok kontrol. Ini berarti terapi murottal terbukti signifikan, bisa dijadikan terapi tambahan dalam pengelolaan kecemasan pasca operasi. terutama pada operasi post ortopedi.

Hipotesis II: kecemasan setelah dilakukan terapi murottal pada pasien yang menjalani operasi ORIF lebih rendah dari sebelum dilakukan terapi murottal.

Bila dilihat dari pengukuran tingkat kecemasan dari pretest hari 1 sampai posttest hari ke 2, diketahui bahwa skor kecemasan pada hari pretest 1 tidak berbeda dengan pretest hari $2(\mathrm{p}>$ 0,05 ). sedangkan pretest hari 1 berbeda secara signifikan dari posttest hari 1 atau posttest hari ke $2(\mathrm{p}<0,05)$ dan posttest hari 1 tidak berbeda dengan posttest hari ke $2(p>0,05)$. Dari data ini dapat disimpulkan bahwa setelah terapi murottal pada hari pertama dan kedua penelitian, skor posttest kecemasan menurun secara signifikan. Tapi pada pretest hari 2, skala kecemasan tidak berbeda dengan pretest hari 1 . Ini berarti responden kembali merasakan tingkat kecemasan pada tingkat yang sama dengan skala nyeri pada pretest hari ke 1. Kemudian, Kecemasan pada posttest hari 1 dan 2 tidak berbeda secara signifikan.

Jika dilihat dari sisi psikologis, seperti yang telah diamati oleh Faradisi (2011), dinyatakan bahwa terapi murottal memiliki efek positif terhadap psikologis. Artinya murottal akan mempengaruhi psikologis pasien dan bisa membuat pasien tenang. Sepertinya kuncinya, 
PROFESI (Profesional Islam)

Media Publikasi Penelitian; 2018; Volume 15; No 2.

Website: ejournal.stikespku.ac.id

mengapa terapi murottal berpengaruh signifikan dalam mengurangi kecemasan dibandingkan dengan kelompok kontrol adalah karena seperti yang kita ketahui bahwa rasa kecemasan bersifat subjektif, maka diperlukan terapi yang dapat mempengaruhi subjektivitas dan perspektif seseorang dalam menanggapi rasa sakit dan kecemasan. Orang Indonesia, terutama orang yang muslim, meyakini bahwa jika penyakit atau tragedi terjadi semua datang dengan izin Tuhan (Al-Quran). Jika seseorang mengalami bencana, seperti patah tulang atau penyakit lainnya, itu adalah masalah yang ditakdirkan oleh Tuhan. Dalam konsep Islam, bencana itu bisa jadi karena dosa yang telah dilakukan atau karena Tuhan ingin menguji kualitas kesabaran dan kepercayaan hamba-hamba-Nya. Orang-orang Muslim juga percaya bahwa saat Anda depresi, cemas atau sedih, maka ketika mengingat Tuhan dapat menenangkan hati, karena dalam ajaran Islam sendiri Tuhan menyatakan bahwa "hanya dengan mengingat AKU (Tuhan), hati akan tenang" (QS Ar-Raad: 28) dan satu cara untuk mengingat dan mendekatkan diri kepada Tuhan adalah dengan membaca atau mendengarkan Alquran (mendengarkan murottal). Jadi ketika peneliti mengusulkan penelitian tentang efek terapi murottal untuk mengurangi kecemasan, kebanyakan pasien rela dan senang ikut berpartisipasi menjadi responden, dan hanya 3 orang yang menolak ikut serta dalam penelitian ini.

Hubungan antara terapi murottal terhadap psikologis pasien dapat dijelaskan sebagai berikut, bila terjadi kerusakan pada tubuh seperti patah tulang dan pembedahan, secara otomatis akan menimbulkan rasa sakit dan kecemasan. Hal ini dapat dibuktikan dengan hasil penilaian pretest rasa sakit dan kecemasan, baik kelompok kontrol maupun kelompok intervensi, rata-rata masih memiliki skala rasa sakit dan kecemasan yang cukup tinggi walaupun memiliki terapi analgesik. Saat peneliti memberi terapi murottal kepada responden, maka saat responden mendengar murottal, itu akan diterjemahkan oleh otak. Persepsi kita ditentukan oleh semua yang telah terakumulasi, keinginan, harapan, kebutuhan dan Pre-Supposiition (Oriordan, 2002). Seperti yang telah dijelaskan sebelumnya, bahwa Islam sangat percaya bahwa ketika sesuatu yang buruk terjadi, kita harus kembali kepada Tuhan, untuk mengingat, dan menyerahkan diri kepada
Tuhan (atau dalam konsep Islam disebut tawakkal). Keinginan dan harapan terbesar dari pasien Muslim yang menjalani operasi adalah bahwa pasien dapat pulih kembali menjadi normal dan kebutuhan terbesar (kebutuhan psikologis dasar manusia) adalah pendukung kekuatan, yaitu kesadaran akan realitas keberadaan Tuhan. Kualitas kesadaran seseorang terhadap Tuhan akan meningkat, kesadaran ini akan mengarah pada penyerahan sepenuhnya kepada Tuhan (akan terbentuk harapan positif atau koping) (Krishna, 2001). Hal ini akan meningkatkan indifidu untuk mengatasi dan membuat jantung lebih tenang saat pasien muslim mencoba merenung dan mendekat kepada Tuhan dengan mendengarkan murottal.

Selanjutnya, ketika pasien mendengar terapi murottal, input murottal akan Mempengaruhi persepsi pikiran (ini dipengaruhi oleh faktorfaktor dari dalam individu, seperti kepercayaan dan penilaian) dan dialog batin yang Terjadi akan Mempengaruhi emosi. Bila pikiran dan emosi terkontrol, maka outputnya adalah harmoni dan kesehatan yang baik (Oriordan, 2002). Hal ini membuat pasien menjadi tenang dan mempengaruhi subjektivitas pasien dalam mengatasi rasa sakit dan kecemasan. Hal ini terbukti ketika peneliti menyelesaikan penilaian kecemasan pasca operasi, peneliti juga menyelidiki penyebab penurunan rasa sakit dan kecemasan, dan ratarata pasien mengatakan, setelah mendengar murottal mereka merasa tenang dan menyerah kepada Tuhan. Ingatlah bahwa Tuhan dapat bekerja sebagai pengalih perhatian dimana daerah otak menjadi beringsut dan menjadi aktif dan ini mengalihkan pikiran pasien dari kecemasan untuk mengingat Tuhan Yang Maha Esa (Kakigi et al., 2005; Febriany, S.N, 2009). Selain itu, pasien merasa tenang dan nyaman karena mereka merasa dekat dengan Tuhan yang membuat mereka lebih rileks (Febriany, S.N., 2009).

\section{REFERENSI}

Akbar (2009). Quran musicality, beauty Element Study of Internal and External sound. [Bachelor Thesis in Islamic theology]. Yogyakarta:Islamic University Sunan Kali Jaga [in Indonesian] 
PROFESI (Profesional Islam)

Media Publikasi Penelitian; 2018; Volume 15; No 2.

Website: ejournal.stikespku.ac.id

Allred et al.,(2010) The effect of music on postoperative pain \& anxiety. Pain managemen nursing, 11, 15-25.

Chapman \& Gavrin. (1999). Suffering contributions of persistent pain.The Lancet, 353, 2233-37.

Engwall M, Duppils G. (2009). Music as a Nursing Intervention for Postoperative Pain: A systematic Review.Journal of Perianesthesia Nursing, 24 (6), 370-383.

Faradisi, F. (2010). Differences Effectivenes Between Murotal Therapy With Music Clasik Therapy To Decline In The Level Of Anxious On Patients Pre Operation Fraktur Extremity [Bachelor Thesis in Adult Nursing]. Surakarta: Muhammadiyah University of Surakarta. [in Bahasa Indonesia]

Good, M. (2008). Korean and American Music Reduces Pain in Korean Women After Gynecologic Surgery. Pain Managemrnt Nursing, 9 (3): 96-103.
Islamic Organisation for Medical Sciences. (2001).Therapeutic Effect of Qur'an reading:A scientific study. Retrieved on may 12, 2014. from: http://www.every muslim.co.za/index.php/articlesmenu/islamic-medicine-menu/1241therapeutic-effect-of-quran-readingascientific-study

Khrisna, A.(2001). Masnawi, Bersama Jalaluddin Rumi Menggapai Langit Biru Tak Berbingkai. Jakarta: PT Gramedia Pustaka Utama.

Oriordan.(2002). Natural Healing Arts, Healing Arts Use Life Energy. Bekasi: Gugus Press.

Potter \& Perry-Stockert-Hall,(2011). Basic Nursing. Canada:Mosby Elsevier. 